January 2001 • NREL/CP-520-28928

\title{
Decade of PV Industry R\&D Advances in Silicon Module Manufacturing
}

M. Symko-Davies, R.L. Mitchell, C.E. Witt, and H.P. Thomas

National Renewable Energy Laboratory

R. King

U.S. Department of Energy

D.S. Ruby

Sandia National Laboratories

Presented at the $28^{\text {th }}$ IEEE PV Specialists Conference Anchorage, Alaska September 17-22, 2000

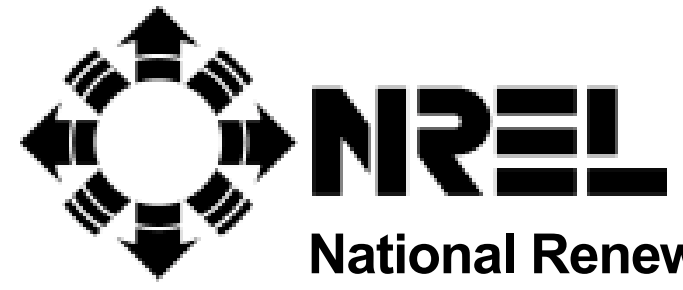

1617 Cole Boulevard Golden, Colorado 80401-3393

NREL is a U.S. Department of Energy Laboratory Operated by Midwest Research Institute $\bullet$ Battelle $\bullet$ Bechtel 


\section{NOTICE}

The submitted manuscript has been offered by an employee of the Midwest Research Institute (MRI), a contractor of the US Government under Contract No. DE-AC36-99G010337. Accordingly, the US Government and MRI retain a nonexclusive royalty-free license to publish or reproduce the published form of this contribution, or allow others to do so, for US Government purposes.

This report was prepared as an account of work sponsored by an agency of the United States government. Neither the United States government nor any agency thereof, nor any of their employees, makes any warranty, express or implied, or assumes any legal liability or responsibility for the accuracy, completeness, or usefulness of any information, apparatus, product, or process disclosed, or represents that its use would not infringe privately owned rights. Reference herein to any specific commercial product, process, or service by trade name, trademark, manufacturer, or otherwise does not necessarily constitute or imply its endorsement, recommendation, or favoring by the United States government or any agency thereof. The views and opinions of authors expressed herein do not necessarily state or reflect those of the United States government or any agency thereof.

Available electronically at http://www.doe.gov/bridge

Available for a processing fee to U.S. Department of Energy and its contractors, in paper, from:

U.S. Department of Energy

Office of Scientific and Technical Information

P.O. Box 62

Oak Ridge, TN 37831-0062

phone: 865.576 .8401

fax: 865.576.5728

email: reports@adonis.osti.gov

Available for sale to the public, in paper, from:

U.S. Department of Commerce

National Technical Information Service

5285 Port Royal Road

Springfield, VA 22161

phone: 800.553 .6847

fax: 703.605.6900

email: orders@ntis.fedworld.gov

online ordering: http://www.ntis.gov/ordering.htm

Printed on paper containing at least $50 \%$ wastepaper, including $20 \%$ postconsumer waste 


\title{
DECADE OF PV INDUSTRY R\&D ADVANCES IN SILICON MODULE MANUFACTURING
}

\author{
Martha Symko-Davies, ${ }^{1}$ Richard L. Mitchell, ${ }^{1}$ C. Edwin Witt, ${ }^{1}$ Holly P. Thomas, ${ }^{1}$ Richard King, ${ }^{2}$ Douglas Ruby ${ }^{3}$ \\ 1 National Renewable Energy Laboratory, Golden, CO; 2 U.S. Department of Energy, Washington, D.C.; and \\ 3 Sandia National Laboratories, Albuquerque, NM
}

\begin{abstract}
The U.S. Photovoltaic (PV) industry has made significant technical advances in crystalline silicon (Si) module manufacturing through the PV Manufacturing R\&D Project during the past decade. Funded Si technologies in this project have been czochralski, cast polycrystalline, edge-defined film fed growth (EFG) ribbon, string ribbon, and Si-film. Specific R\&D Si module-manufacturing categories that have shown technical growth and will be discussed are in crystal growth and processing, wafering, cell fabrication, and module manufacturing. These R\&D advancements since 1992 have contributed to a $30 \%$ decrease in PV manufacturing costs and stimulated a sevenfold increase in $\mathrm{PV}$ production capacity.
\end{abstract}

\section{INTRODUCTION}

Initial work under the PV Manufacturing R\&D Project began in 1990 with a Photovoltaic Manufacturing Technology (PVMaT) solicitation. This solicitation and all subsequent ones under this project were structured as a joint R\&D partnership between the Federal government (through the U.S. Department of Energy) and individual members of the U.S. PV industry. The focus of the solicitations was on helping the U.S. PV industry improve module-manufacturing processes and equipment; accelerate manufacturing cost reductions for PV modules; improve balance-of-systems components and integrated systems; increase commercial product performance and reliability; and enhance investment opportunities for substantially scaling up U.S. manufacturing capacity and increasing U.S. market share. Currently, the project is in its tenth year, with the focus on PV System and Component Technology and PV Module Manufacturing Technology. The project does not specify any particular manufacturing technology. Historically, the project has included a large number of crystalline-Si manufacturers, which represent the majority of the U.S. PV production capacity.

This paper addresses several key areas of silicon manufacturing processes that have shown growth during this project. Crystalline Si R\&D manufacturing categories that have shown technical advances and that will be discussed are crystal growth and processing, wafering, cell processing, and module manufacturing. Specific advances have included wafer size and volume, wafer thickness, the size of ingots/boules/sheets/ribbon, and throughput and yield. Finally, the success resulting from these PV R\&D advancements will be detailed in an evaluation of modulemanufacturing costs and total manufacturing capacity data collected from the crystalline $\mathrm{Si}$ industry participants in this project.

\section{HISTORY}

Early 1990, beginning with the problem-identification phase of this project, ${ }^{1} \mathrm{Si}$ issues were focused on transforming the $\mathrm{PV}$ industry. The current projections are to reach a capacity of $380 \mathrm{MW} /$ year at a cost of $\$ 1.35 /$ watt by the year 2005 (see Figs. 1 and 2 for project industry predictions). In order to plan for such a capacity and enable its economic feasibility, the manufacturing industry identified a means to achieve these goals through the PV Manufacturing R\&D project.

The specific flat-plate $\mathrm{Si}$ technologies that were awarded cost-shared subcontracts continuously throughout the project are czochralski, cast polycrystalline, edgedefined film fed growth (EFG) ribbon, string ribbon, and Sifilm. Table 1 shows the conversion efficiencies for production cells and modules for the different crystalline $\mathrm{Si}$ technologies prior to these R\&D efforts.

\begin{tabular}{|l|c|c|}
\hline \multicolumn{1}{|c|}{ Material } & Cell $^{*}$ & $\begin{array}{c}\text { Module } \\
\text { (Total Area) }\end{array}$ \\
\hline Czochralski & 13 & 12 \\
\hline Cast Poly & 11.8 & $10-11$ \\
\hline EFG Ribbon & 12 & 10 \\
\hline String Ribbon & $10-12$ & - \\
\hline Si-Film & 9.5 & - \\
\hline
\end{tabular}

${ }^{*}$ Production

Table 1. Pre-PVMaT Crystalline Silicon PV Conversion Efficiencies (\%).

Table 2 shows the most recent conversion efficiencies for crystalline Si by technology. Although this project is not responsible for all of the total efficiency increases through R\&D advances, it has played a substantial role. 
Significant production efficiency increases can be seen during the past decade for each of these Si technologies.

\begin{tabular}{|l|c|c|}
\hline \multicolumn{1}{|c|}{ Material } & Cell $^{*}$ & $\begin{array}{c}\text { Module } \\
\text { (Total Area) }\end{array}$ \\
\hline Czochralski & 14 & 12.7 \\
\hline Cast Poly & 12.5 & 12.8 \\
\hline EFG Ribbon & 14 & 12 \\
\hline String Ribbon & 13 & - \\
\hline Si-Film & 13.3 & 10 \\
\hline
\end{tabular}

*Production

Table 2. Current Crystalline Silicon PV Conversion Efficiencies (\%).

\section{R\&D ADVANCEMENTS}

The last decade has brought many R\&D advancements to solar cell manufacturers with focus on cost reduction, increased capacity and profitability. ${ }^{2}$ Even though no two solar cell manufacturers have the same process sequence it seems appropriate to categorize these R\&D advancements in the following manufacturing areas 1) Crystal Growth and Processing, 2) Wafers, 3) Cells and, 4) Module Production. Table 3 displays R\&D advancements from 1991-2000 by percentage increase in production (MW) for each category. The average production levels shown are weighted averages (weighted by each participant's capacity), which represent $95 \%$ of the U.S. industry production. $^{3}$ In some cases we did not receive complete information from the industry. All data shown below are weighted averages.

It can be seen from Table 3 that the largest percentage increase in production was in the category of Wafers, with Crystal Growth and Processes, and Modules closely following. The categories are all coupled and highly dependent on one another(e.g. if the PV Manufacturers can transfer $20 \%$-efficient, $175-\mu \mathrm{m}$-thick, $36-\mathrm{cm}^{2}$ cells to manufacturing operations, this will reduce the number of PV-manufacturing growers and wire saws, increasing module production).

\begin{tabular}{|l|c|}
\hline \multicolumn{1}{|c|}{ Categories } & $\begin{array}{c}\text { \% Increase in } \\
\text { Production }\end{array}$ \\
\hline Crystal Growth and Processes & 700 \\
\hline Wafers & 863 \\
\hline Cells & 306 \\
\hline Modules & 668 \\
\hline
\end{tabular}

Table 3. R\&D Advancements From 1991-2000 Displayed By the Percentage Increase in Production (MW).

\section{Crystal Growth and Processing}

During the years 1991-2000, the PV industry made significant advances in the areas of (1) polycrystalline feedstock, (2) throughput, and (3) quality of the material, which resulted in reduced manufacturing costs and increased production yields. Specifically, these include lowered cost and improved quality feedstock material, decreased metallic impurities, and grain boundary and dislocations, larger sized ingots/planks/ribbons/boules, increased growth speeds, and lowered environmental costs (i.e., waste reductions, reducing kerf loss, and yielding thinner wafers through improved material properties). A $122 \%$ increase in Ingot/boule/sheet/ribbon throughput and a $202 \%$ increase in the number of growers occurred. These R\&D advances have resulted in a $700 \%$ increase in production for Si manufacturers over this time period.

\section{Wafers}

Cutting of ingots, boules, planks or ribbons can involve material breakage or loss. Several cost-effective applications of wire saws and high-speed lasers were improved and implemented. The center-to-center cut distances were decreased, which improved downstream yields. ${ }^{4}$ With these developments, wafers could then become thinner and larger, while increasing the cell throughput. Resulting wafer thickness was reduced by $31 \%$, and the size of the wafer increased by $122 \%$. The total percentage increase in production over this time period due to this category was $863 \%$. With the feedstock issues still vital to the Si industry, these cutting technologies have been, and still remain crucial to their future in production.

\section{Cells}

The cell-fabrication process has undergone several transitions and developments throughout the project. The areas of improvements and implementations include: gettering and passivation/hydrogenation, damage etching, belt diffusions, emitter junctions, texturing-uniformity issues, anti-reflective (AR) coatings, back surface fields (BSF), screen printing, and process monitoring. Significant changes were identified when going from tube diffusions to belt diffusions, incorporating BSFs, and conversions to silicon nitride AR coatings. Cell efficiencies effectively increased with in-line optimization and throughput. ${ }^{4,5}$ The production cell performance increased by $15 \%$ efficiency, and the output improvements increased by $191 \%$ with a total production increase of $306 \%$.

\section{Modules}

To decrease the final module manufacturing costs, advances were made towards high yields, redesigning of junction-boxes, frameless modules, back-skin material, integration of interconnect/lamination/fabrication processes, 
development of larger modules with larger cells, improved packing density, and automation assembly for reducing labor content. These R\&D advancements in module manufacturing contributed to a $668 \%$ increase in production.

\section{Significant R\&D Advancements}

Much growth and maturity has been accomplished by the Si PV manufacturers over the past decade through the project. Table 4 highlights the significant PV Manufacturing R\&D Advancements that have occurred during the past decade for a large portion of the PV industry. The number of growers and ingot/boule/sheet/ribbon throughput have increased, and wafer thickness has decreased. Cell size, cell performance and product throughput have all increased. This table indicates that long-term optimism for continuing these R\&D Advances is valid.

\begin{tabular}{|l|c|}
\hline \multicolumn{1}{|c|}{ R\&D Advancement } & $\begin{array}{c}\text { Average } \% \\
\text { Increase }\end{array}$ \\
\hline Increased Number of Growers & $202 \%$ \\
\hline Increased Ingot/boule/sheet/ribbon & $122 \%$ \\
\hline Reduced Wafer thickness & $25 \%$ \\
\hline Increased Cell Size & $50 \%$ \\
\hline Increased Performance & $15 \%$ \\
\hline Output Improvements & $192 \%$ \\
\hline
\end{tabular}

Table 4. Hilights of the Si R\&D Advancements From 19912000.

\section{COST/CAPACITY ANALYSIS}

Cost and capacity analysis of the Si PVMaT manufacturers provides a method of evaluating the R\&D advances that have occurred during the past decade. Figure 1 shows the weighted-average direct Si module manufacturing costs versus year. ${ }^{6}$ The "average module manufacturing cost" represents the average cost per watt of modules (weighted by each participant's capacity for these five Si participants). Module costs for years 1992-1999 are based on each of the manufacturer's module-production capacity level and include only those costs directly associated with the manufacturing of modules (i.e., marketing, administration, or sales are not included). ${ }^{7}$ The data shown before the year 2000 are considered historical after this point they are projected. The "average modulemanufacturing cost" seen in this figure will have decreased by the year 2005 to $\$ 1.48 \mathrm{Wp}$. A shift of data should be expected to occur as data become historical as opposed to optimistic.

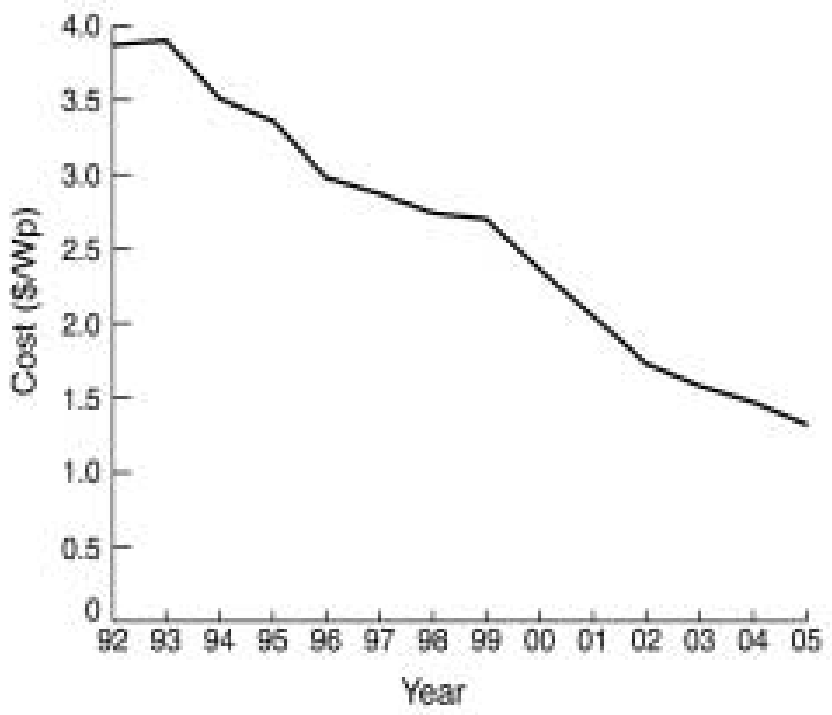

Fig. 1. Cost vs. Year for Five Si manufacturing R\&D Participants

Figure 2 shows the total production capacity for the participants versus year. Data in this figure are based on each manufacturer's maximum production capacity (in MW) during a given year (actual and projected). The capacity will have reached $375 \mathrm{MW}$ by the year 2005. The Si R\&D advancements since 1992 have contributed to a $30 \%$ decrease in manufacturing costs and a sevenfold increase in production capacity.

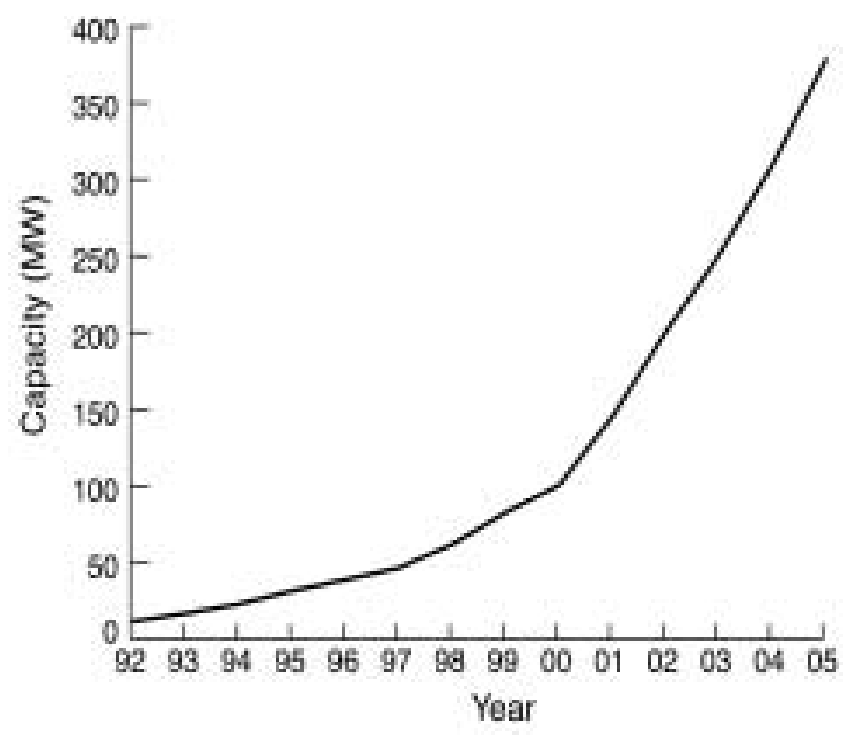

Fig. 2. Capacity vs. Year for Five Si Manufacturing R\&D Participants 


\section{CONCLUSIONS}

R\&D advancements during the past decade have led to significant increases in the production for Crystal Growth and Processes, Wafers, Cells and Modules. The Ingot/boule/sheet/ribbon size has increased by $122 \%$, and the number of growers has increased by $202 \%$. Additionally, cell sizes have increased by $50 \%$, cell thickness has been reduced by $31 \%$, performance has increased by $15 \%$, and output yields have improved by $191 \%$. These Si R\&D advancements since 1992 have contributed to a $30 \%$ decrease in manufacturing costs and a sevenfold increase in production capacity.

Increased yields, more efficient production, and consequently lower costs have resulted from advances in module manufacturing R\&D, making this an exciting decade for the PV Manufacturing R\&D Project, industry, and government. Viewing the advances in PV technology together with the results of the cost/capacity analysis justifies a strong, long-term optimism that can expect sustained improvements into the next decade.

\section{ACKNOWLEDGMENTS}

This work is supported under DOE Contract No. DEAC36-99G010337 with NREL. Many people have contributed to the development and implementation of the Photovoltaic Manufacturing Technology project and to the R\&D efforts carried out in this program. The authors recognize that this paper represents their work.

\section{REFERENCES}

[1] C.E. Witt, L.O. Herwig, R. Mitchell, G.D. Mooney, "Status of the Photovoltaic Manufacturing Technology (PVMaT) Project", Proc. 22 ${ }^{\text {nd }}$ IEEE PVSC, Las Vegas, NV, 1991.

[2] James Rand, Ralf Jonczyk, "Silicon Solar Cell Manufacturing 10 Years of Volume Growth and Cost Reduction," $10^{\text {th }}$ Workshop on Crystalline Silicon Solar Cell Materials and Processes, CO, Aug. 2000.

[3] Paul Maycock, PV News, Volume 19/NO2, February 2000.

[4] John H. Wohlgemuth-BP Solarex, "Cast Polycrystalline Silicon Photovoltaic Cell and Module Manufacturing Technology Improvements," NCPV Photovoltaics Program Review, 1999, p. 747-752.

[5] Theresa L. Jester-Siemens Solar, Photovoltaic CZ Silicon Manufacturing Technology Improvements, NCPV Photovoltaics Program Review, 1996, p. 326.

[6] C.E. Witt, et.al., "Ten Years of Manufacturing R\&D in PVMaT - Technical Accomplishments, Return on Investment, and Where Do We Go Next," Submitted to the IEEE PVSC 2000 Conference.

[7] R.L. Mitchell, C.E. Witt, H.P. Thomas, L.O. Herwig, D.S. Ruby, Richard King, and C.C. Aldrich,"Progress Update on The U.S. Photovoltaic Manufacturing Technology Project," Proceedings of the 26th IEEE Photovoltaics Specialists Conference, Anaheim, CA, 1996. 


\section{REPORT DOCUMENTATION PAGE}

Form Approved OMB NO. 0704-0188

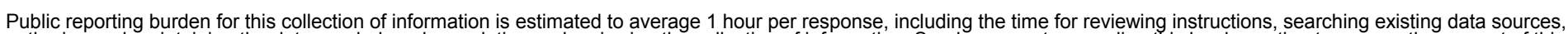

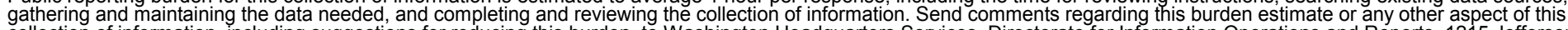

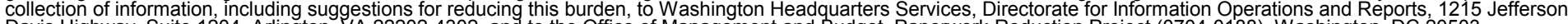
Davis Highway, Suite 1204, Arlington, VA 22202-4302, and to the Office of Management and Budget, Paperwork Reduction Project (0704-0188), Washington, DC 20503.

\begin{tabular}{|l|l|l} 
1. AGENCY USE ONLY (Leave blank) & $\begin{array}{l}\text { 2. REPORT DATE } \\
\text { January } 2001\end{array}$ & $\begin{array}{l}\text { 3. REPORT TYPE AND DATES COVERED } \\
\text { Conference Proceedings }\end{array}$
\end{tabular}

4. TITLE AND SUBTITLE

Decade of PV Industry R\&D Advances in Silicon Module Manufacturing

5. FUNDING NUMBERS

6. $\mathrm{AUTHOR}(\mathrm{S})$

M. Symko-Davies, R.L. Mitchell, C.E. Witt, H.P. Thomas, R. King, D. Ruby

C:

TA: PVP1.6101

7. PERFORMING ORGANIZATION NAME(S) AND ADDRESS(ES)

8. PERFORMING ORGANIZATION REPORT NUMBER

10. SPONSORING/MONITORING AGENCY REPORT NUMBER

\section{National Renewable Energy Laboratory}

1617 Cole Blvd.

Golden, CO 80401-3393

NREL/CP-520-28928

11. SUPPLEMENTARY NOTES

12a. DISTRIBUTION/AVAILABILITY STATEMENT

National Technical Information Service

U.S. Department of Commerce

5285 Port Royal Road

Springfield, VA 22161

13. ABSTRACT (Maximum 200 words)

The U.S. Photovoltaic (PV) industry has made significant technical advances in crystalline silicon (Si) module manufacturing through the PV Manufacturing R\&D Project during the past decade. Funded Si technologies in this project have been Czochralski, cast polycrystalline, edge-defined film-fed growth (EFG) ribbon, string ribbon, and Si-film. Specific R\&D Si module-manufacturing categories that have shown technical growth and will be discussed are in crystal growth and processing, wafering, cell fabrication, and module manufacturing. These R\&D advancements since 1992 have contributed to a $30 \%$ decrease in PV manufacturing costs and stimulated a sevenfold increase in PV production capacity.

14. SUBJECT TERMS

photovoltaics; PV Manufacturing R\&D Project; PVMaT; crystalline silicon; R\&D

advancements; crystal growth and processing; wafers; cells; modules; cost/capacity analysis

17. SECURITY CLASSIFICATION OF REPORT Unclassified
18. SECURITY CLASSIFICATION OF THIS PAGE Unclassified
19. SECURITY CLASSIFICATION OF ABSTRACT Unclassified
15. NUMBER OF PAGES

16. PRICE CODE

20. LIMITATION OF ABSTRACT

UL 